\title{
International Economics: Rattan
}

Immaculata Gabriella Utomo

Faculty of Business and Economics, University of Surabaya

gabriellautomo01@gmail.com

\section{INTRODUCTION}

Rattan is an influential source of livelihood that greatly affects the income of local people who depend on forest resources especially the non-wood forest produce and it belongs to Arecaceae/Palmae and has Calamoideae as the subfamily (Rozali, Masum, Zakaria, Mansor, \& Othman, 2014). Rattan has many conveniences compared to wood in general, which makes it has its own attractive value. The superiority of rattan can be felt from its lighter weight compared to wood, cheaper price, stronger, and not to mention the level of elasticity. Rattan grows in areas that have a subtropical and tropical climate. Indonesia is the largest supplier of rattan in the world by topping more than half percentages of the world's rattan supply followed by other tropical and subtropical countries such as Malaysia, the Philippines, Sri Lanka, and Bangladesh. Even though Indonesia topping the world's rattan supply, to maintain the industry of rattan in Indonesia thus in 2011 the Ministry of Commerce issued a complete ban or prohibition for exporting raw rattan (Pratono, 2019). The reason for the prohibition's, set because of the exploitation of Indonesia's forest by irresponsible parties.

Absolute advantage by Adam Smith and comparative advantage by David Ricardo principally related to the comparison of technological superiority within a country and another to excel commodity production (Gupta, 2015). The absolute advantage is focusing on country commodity production that has a higher level of productivity and lower cost compared to another country. Meanwhile, the comparative advantage focusing on higher relative productivity rather than the higher absolute productivity. The improvement of quality and quantity investment by countries happens because of the realization of their essential elements important in competitive advantage (Pratono, 2019). Trade is possible because of the conditions whereas economy-wide supply differences can cause the relative autarky price differences too which make this the pattern of comparative advantage (Reinert, 2012). Global Value Chains that refer cross-cultural collaboration can benefit a country because every country has its own superiority in a certain field, thus with collaboration, it can boost a country's export and assist the country to increase the deficiencies of other fields. 


\section{CONCLUSION}

The pattern of comparative advantage that determines the mutual gains of trade in the world economy is relevant in the rattan industry business. This shows from the partnership between Indonesia and the Philippines with the trade of rattan and optical machine. Indonesia which is the world's largest supplier for rattan industry has made the Philippines choose to import rattan from Indonesia even though the Philippines also exporting rattan. The choice to import rattan can be from Indonesia's lower price from the Philippines perspective. Thus, the cost of producing rattan can be allocated to increase the Philippines exports in other fields. On the other hand, the Philippines' superiority in terms of producing optical machines makes Indonesia choose to import from the Philippines because it may cost higher for Indonesia if making the optical machine by itself. The Philippines' high interest in design make the country demand for raw rattan increasing, in contrast with Indonesia that has abundant raw rattan supply but lower demand in the designed product of rattan. The trade can be beneficial for both parties to increase productivity in their rattan industry. Meanwhile, the high population of Indonesia has made the optical machine demand is increasing and the fastest way to fulfill the market demand is through importing from the Philippines. This situation meaning that both countries experience the comparative advantage of mutual gains through trading.

Fairtrade can be promoted through its relevancy with one of the typologies in cross-cultural collaboration. Producer-driven is the relevance typology to promote fair trade. In producerdriven, the developed countries' leading firm tends to build a strong relationship with emerging economies with the farmers itself (Pratono, 2019). This can help the small farmer to understand better the quality improvement and exploring innovation that attracts the rattan globally. Fairtrade indicates a trustworthy long-term partnership that grounded with good communication, respect, and transparency between the countries. It also helps to study a new approach to naturalized market imbalances which peculiarly happen with small farmers that generate in the market system and production. Thus, fairtrade can boost domestic small farmers and developing the country itself. The role of producer-driven in design company global value chain is to develop a country (Pratono, 2019). This shows the engagement between the fairtrade and producer-driven typology. For instance, the small farmer of raw rattan can expand their supply not only for domestic needs but globally through the leading firms in developed countries. The market imbalance such as exceed supply in domestic market will gradually be minimized and long-term collaboration is possible. Thus, to promote fair trade producer-driven is the right typology, even if, the opportunity to gain a competitive advantage is not possible with the banned export. 


\section{REFERENCES}

Rozali, W. N., Masum, K. M., Zakaria, R., Mansor, A., \& Othman, A. S. (2014). Species diversity and abundance of rattan in offshore hill reserve forest of peninsular Malaysia along the elevation gradient. The Journal of Bamboo and Rattan, 13.

Pratono, A. H. (2019). Cross-cultural collaboration for inclusive global value chain: a case study of rattan industry. International Journal of Emerging Markets.

Gupta, S. D. (2015). Comparative Advantage and Competitive Advantage: An Economics Perspective and a Synthesis. Athens Journal of Business and Economics.

Reinert, K. A. (2012). An Introduction to International Economics. United States of America: Cambridge University Press. 